\title{
A STUDY ON VOCAL CORD LESIONS
}

\begin{tabular}{ll}
\hline ENT & \\
$\begin{array}{ll}\text { Dr. Manas Ranjan } \\
\text { Rout }\end{array}$ & (Professor of ENT) \\
\hline Dr. Fathima* & (Postgraduate) *Corresponding Author \\
\hline
\end{tabular}

\section{ABSTRACT}

Introduction - Vocal cord lesions may be benign or malignant or pseudotumors. Patients usually come to us with symptoms of hoarseness of voice, cough, foreign body sensation, or throat pain. The patient should be evaluated properly to find out the causes. A malignant condition should be detected as early as possible to give prompt treatment and the best prognosis.

Aim and objectives - To study the clinical and pathological behavior of vocal cord lesions.

Materials and methods -30 cases of vocal cord lesions were studied.

Results - Commonest age group is $61-70$ years (36.7\%). The male to female ratio is 3.28:1. Hoarseness of voice is the commonest symptom followed by cough. Smoking and alcohol are the commonest predisposing factor followed by vocal abuse. The commonest vocal cord lesion is the malignancy (squamous cell carcinoma) (56.6\%) and the commonest benign condition is the vocal polyp (30\%).

\section{KEYWORDS}

Vocal cord, malignant lesion, vocal polyp

\section{INTRODUCTION}

Primary disorders of vocal cords can be grouped into true neoplasms[benign or malignant] and pseudotumors. ${ }^{[1]}$

Pseudo tumors include vocal cord nodules, polyps, cysts, and hyperplastic changes. Vocal cord nodules round whitish-grey neoplasms, $<3 \mathrm{~mm}$ diameter, located symmetrically bilateral on free edge at junction of anterior and middle $1 / 3^{\text {rd }}$ of true vocal cord.these are most commonly seen in boys and women ${ }^{[1,2,3]} \cdot 17-24 \%$ cases are commonly seen in singers ${ }^{[1]}$. Polyps are very common benign, nonneoplastic conditions which are small pedunculated or sessile lesions, unilateral or bilateral, located at anterior $1 / 3^{\text {rd }}$ of the free edge of the vocal $\operatorname{cord}^{[1,3]}$. In $82 \%$ cases, hoarseness is presenting symptom ${ }^{[1]}$. Smoking and voice abuse are major risk factors ${ }^{[1]}$. Reinke's edema, either unilateral or bilateral, sessile bleach white swelling filled with fluid $^{[1,2]}$. Smoking and avid voice use are major risk factors ${ }^{[1,2]}$

Metabolic deposits like amyloidosis, gout, and foreign body granulomas can cause distension of vocal cords ${ }^{[1]}$. Intubation granuloma occurs in patients who have undergone endolaryngeal surgery, acute or chronic intubation, and rigid bronchoscopy ${ }^{[2]}$. Foreign body granulomas can be caused by the substances used to medialize the vocal fold, on the side of vocal fold immobility like Teflon, collagen, fat, and room temperature vulcanizing silicone and hydroxyapatite ${ }^{[1]}$. Chronic exposure to asbestos is another factor ${ }^{[1]}$

Benign lesions may be either neoplastic or non-neoplastic. Non neoplastic lesions include saccular cysts, laryngoceles, other laryngeal cysts like supraglottic ductal cysts, inclusion cysts, intracordal vocal fold cysts, and pseudocysts ${ }^{[1]}$. Saccular cysts, either congenital or acquired are secondary to the narrowing of the saccular lumen located at the anterior end of the laryngeal ventricle $e^{[1,2]}$. Laryngocele is an abnormal dilation of the laryngeal saccule that maintains communication with the laryngeal lumen ${ }^{[1,2]}$. Neoplastic lesions include papilloma, paraganglioma chondroma ,granular cell tumours,neurilemmoma,neurofibroma oncocytoma, leiomyoma, rhabdomyoma and lipoma ${ }^{[1,2]}$.Papilloma is the most common benign neoplasm of the larynx caused by human papilloma virus[HPV], most common subtypes including $6 \mathrm{c}$-f and $11^{[1,2,3]}$

Laryngeal malignancy, although a relatively rare disease, most frequent cancer of the head and neck, second most common respiratory cancer preceded by lung malignancy ${ }^{[1]}$. It is the eleventh most common cancer worldwide ${ }^{[3]}$. It accounts for for $1 \%$ of all cancer mortality rates estimating roughly 2 lakh deaths annually worldwide ${ }^{[1]}$. Smoking and alcohol consumption are regarded as major risk factors ${ }^{[1,2,3]}$. Glottic cancer accounts for $59 \%$ of laryngeal malignancies and hoarseness of voice is the cardinal symptom ${ }^{[1]}$. Squamous cell carcinoma represents $85-90 \%$ of all malignant laryngeal neoplasms ${ }^{[1]}$.

Benign vocal fold lesions, polyps, being most common, impacts the

quality of life, primarily voice production ${ }^{[1,2]}$. More than $50 \%$ of patients with voice complaints have benign mucosal disorder ${ }^{[2]}$. Laryngeal malignancies can be a significant source for mortality and morbidity, and in cases of glottic cancers, they present early with voice chang $\mathrm{e}^{[3]}$. So early and accurate diagnosis plays a crucial role, as early tumors can successfully be treated with radiotherapy with five year survival rates $>75 \%$.

\section{AIMS AND OBJECTIVES}

1) To study the clinical and pathological behavior of vocal cord lesions.

\section{MATERIALS AND METHODS}

This is a retrospective study carried out in a tertiary care center of south India for a period of 2 years. All patients coming with vocal cord complaints like hoarseness of voice, voice fatigue, chronic cough, dyspnoea, and neck nodes were evaluated properly with the general examination, indirect laryngoscopy, and video laryngoscopy.

A total of 30 patients were selected for the study. Out of all these patients, 22 patients underwent microlaryngeal surgery and removal of the lesion, 8 patients underwent direct laryngoscopy and biopsy. 3 patients underwent emergency tracheostomy followed by direct laryngoscopy. Histopathological study was done in all the cases and then definitive treatment started.

\section{RESULTS}

Table1 : Age and sex distribution

\begin{tabular}{|c|c|c|c|c|}
\hline Age & male & Female & Total & Percentage (\%) \\
\hline $20-30$ & 2 & 0 & 2 & 6.6 \\
\hline $31-40$ & 1 & 4 & 5 & 16.7 \\
\hline $41-50$ & 4 & 0 & 4 & 13.4 \\
\hline $51-60$ & 4 & 2 & 6 & 20 \\
\hline $61-70$ & 10 & 1 & 11 & 36.7 \\
\hline$>60$ & 2 & 0 & 2 & 6.6 \\
\hline Total & 23 & 7 & 30 & 100 \\
\hline
\end{tabular}

Table 1 shows age and sex distribution in vocal cord lesions. It shows that males are more commonly affected than females (Male: Female ratio is 3.28: 1). The most common age group of vocal cord lesion is $61-70$ years i.e. $36.7 \%$ and the least common age group is $20-30 \mathrm{yrs}$ and more than 60 years i.e. $6.6 \%$ each. Youngest patient in our study is 21 year and oldest is 68 year.

Table 2: Distribution of symptoms among patients $[n=30]$

\begin{tabular}{|l|l|l|}
\hline Symptoms & $\begin{array}{l}\text { Total no of } \\
\text { patients }\end{array}$ & Percentage(\%) \\
\hline Hoarseness of voice & 28 & 93.3 \\
\hline Foreign body sensation in the throat & 12 & 40 \\
\hline Cough & 11 & 36.6 \\
\hline Pain in the throat & 3 & 10 \\
\hline
\end{tabular}




\begin{tabular}{|l|l|l|}
\hline Difficulty in breathing & 3 & 10 \\
\hline Difficulty in swallowing & 5 & 16.6 \\
\hline Cervical lymphadenopathy & 2 & 6.6 \\
\hline Referred otalgia & 2 & 6.6 \\
\hline
\end{tabular}

Table 2 shows the distribution of symptoms among the patients. Hoarseness of voice is the most common presenting symptom found in $93.3 \%$ cases. It was found that some patients were having multiple symptoms.

Table 3: Duration of symptoms in patients

\begin{tabular}{|l|l|l|}
\hline $\begin{array}{l}\text { Duration of symptoms[in } \\
\text { months] }\end{array}$ & $\begin{array}{l}\text { Total Number of } \\
\text { patients }\end{array}$ & $\begin{array}{l}\text { Percentage } \\
(\mathbf{\%})\end{array}$ \\
\hline $0-3$ & 16 & 53.4 \\
\hline $3-6$ & 11 & 36.7 \\
\hline $6-12$ & 2 & 6.6 \\
\hline$>12$ & 1 & 3.3 \\
\hline
\end{tabular}

Table 3 shows the duration of symptoms in patients, where a maximum number of patients were presented with symptoms less than 3 months i.e. $53.4 \%$. Only one patient was presented with the symptom for more than 12 months.

Table 4: Predisposing factors for vocal cord lesions

\begin{tabular}{|l|l|l|}
\hline Predisposing factor & Total & Percentage (\%) \\
\hline Vocal abuse & 10 & 33.4 \\
\hline Smoking[only] & 5 & 16.6 \\
\hline Alcohol[only] & 1 & 3.3 \\
\hline Smoking +alcohol & 11 & 36.7 \\
\hline $\begin{array}{l}\text { Exposure to carcinogens[wood } \\
\text { dust,paints,fumes and coal] }\end{array}$ & 3 & 10 \\
\hline
\end{tabular}

Table 4 shows the predisposing factors for vocal cord lesions. The synergistic effect of smoking and alcohol is the major risk factor for vocal cord lesion i.e. $36.7 \%$ cases followed by vocal abuse (33.4\%)

\section{Table 5: Occupation of patients}

\begin{tabular}{|l|l|l|}
\hline Occupation & Total & Percentage (\%) \\
\hline Daily laborer & 16 & 53.3 \\
\hline Singers/school teachers/church fathers & 6 & 20 \\
\hline Business people & 6 & 20 \\
\hline Housewives & 2 & 6.6 \\
\hline
\end{tabular}

\section{Table 6 shows the distribution of lesions}

\begin{tabular}{|l|l|l|}
\hline Type of lesion & No of patients & Percentage (\%) \\
\hline Vocal polyps & 9 & 30 \\
\hline Vocal nodules & 3 & 10 \\
\hline Squamous papilloma & 1 & 3.4 \\
\hline Malignancy & 17 & 56.6 \\
\hline Total & 30 & 100 \\
\hline
\end{tabular}

Table 6 shows the distribution of different pathological lesions of the vocal cord. Out of 30 patients, the majority are malignant lesions $(56.6 \%)$. Benign lesions are found in $43.4 \%$ cases among which vocal polyp is commonest $(30 \%)$.

Among the 17 cases of glottis malignancy, all were well-differentiated squamous cell carcinoma.

\section{DISCUSSION}

Age :

In our study, the majority of the patients with vocal cord lesions were in the age group of 61 to 70 years i.e. $36.7 \%$. The youngest patient in our study is 21 years and the oldest is 68 year. A study by Hegde $\mathbf{M ~ C}$ et al, shows that the maximum number of cases are in the age group between 31 to 40 years for benign lesion of the larynx $x^{4}$. Youngest patient in their series is 7 year old and the oldest patient is 80 year old ${ }^{4}$. A study by Rameshkumar $\mathbf{E}$ et al, shows that the prevalence of vocal cord lesion with hoarseness of voice is more in age group of $30-50$ years ${ }^{5}$. A study by Shama DK et al, shows that the benign tumors are more common in third decade, where as the malignant tumors are common between the age of $40-70$ years ${ }^{6}$.

Sex:

In our study, there is male predominance and male to female ratio is $3.28: 1$. Male to female ratio is $1: 1$ in the study by Rameshkumar et al . Male to female ratio is $2.82: 1$ in the study by Hegde MC et $\mathbf{a l}^{4}$. Sharma et al told that both benign and malignant tumors are more common in male as compared to female ${ }^{6}$.
Symptomatology :

In our series, maximum number of patients were presented with hoarseness of voice i.e. $93.3 \%$, followed by foreign body sensation of throat $(40 \%)$ and cough $(36.6 \%)$. Majority of the patients were presented withe symptoms within 3 months i.e. $53.4 \%$. In the study of Sharma DK et al, hoarseness of voice was found in $100 \%$ cases and majority of the patients presented with symptoms more than 6 months . Bakshi et al in their study found that hoarseness was the most common complaint. Other complaints were sore throat, neck nodes, and hemoptysis

\section{Predisposing factors:}

In our study, major predisposing factor for vocal cord lesion is the use of both alcohol and smoking i.e. $36.7 \%$, followed by vocal abuse i.e. $33.4 \%$. In the study of Sharma DK et al, the most common predisposing factor is smoking $(25 \%)$ followed by vocal strain $(20 \%)$ and poor orodental hygiene $(20 \%)^{6}$. Maier et al, in a study of 164 cases found that smoking and drinking alcohol increase the dose-dependent risk of laryngeal cancer ${ }^{8}$. Kaufman and Burke ${ }^{9}$ and Adams et al ${ }^{10}$ also stated that tobacco and alcohol abuse is associated with an increase risk of laryngeal cancer.

\section{Occupation :}

In our study, the major occupation affected is the daily laborers i.e. $53.3 \%$. It correlates with the study of Sharma et $\mathbf{a l}^{6}$. Bakshi et al in their study found that $45 \%$ of patients were farmers and $39 \%$ were labourers ${ }^{\text {? }}$.

\section{Pathology:}

In our study, the majority of the lesions are malignant i.e. $56.6 \%$, out of which all are well-differentiated scams cell carcinoma. The vocal polyp is the most common benign condition of the vocal cord i.e. $30 \%$. According to Sharma DK et al, squamous cell carcinoma is the most common malignant tumor detected in the larynx. And out of benign conditions, $70 \%$ were vocal polyp.

\section{CONCLUSION}

The present study concludes that the lesions of the larynx are common in the age group of $61-70$ years. The most common presenting symptom is hoarseness of voice. The commonest predisposing factor is the use of both smoking and alcohol followed by vocal abuse. Daly laborers are mostly affected. The commonest malignant tumor is squamous cell carcinoma and the commonest benign condition is a vocal polyp.

\section{REFERENCES}

1. Fredrick.G.Dikkers, Nodules, polyps, Reinke's edema, metabolic diseases, and foreign body granulomas, Diseases of larynx by Alfio ferlito,Paras publishers Hyderabad,2000,287-290.

2. Robert.W.Balistan,Benign vocal fold mucosal disorders,Cummings otolaryngology head and neck surgery 4 the edition,volume-two, 2005,2150-2186.

3. Julian Mc Gastian,Disorders of voice,Scott browns otolaryngology,head and neck surgery,volume-two,2008,2192-2210.

4. Hegde MC, Kamath MP, Bhojwani K, Peter R, Babu PR; Benign lesions of larynxclinical study, IJOHNS, Vol 57, No 1, Jan - March 2005: 35 - 38

5. Rameshkumar E, Rosmi TK, Prevalence of age, gender and pathological conditions in vocal cords leading to hoarseness of voice in a tertiary care hospital; Int J Adv Med, April - June 2016; Vol 3, Issue 2: 345 - 348 .

6. Shama DK, Sohal BS, Bal MS, Aggarwal S; Clinicopathological study of 50 cases of tumors of larynx, IJOHNS, July 2013, 65 (Suppl 1): S29-S35

7. Bakshi J, Panda NK, Sharma S, Gupta AK, Mann SBS (2004), Survival pattern in treated cases of carcinoma larynx in North India: a 10 years follow up study, Ind JOHNS 56(2): $99-103$

8. Maier H, Gewelke U, Dietz A, Heller W (1992); Risk factors of cancer of the larynx: results of the Heidelberg case- control study; Otolaryngol Head Neck Surg 107(4); 577 582

9. Kaufman JA, Burke AJ (1997), The etiology and pathogenesis of laryngeal carcinoma In: The otolaryngologic clinics of North America, Current Concepts in laryngeal cancer I30(1): 1 - 13

10. Adams GL, Maisel RH (1998), Malignant tumors of the larynx and hypopharynx. In Cummings CW, Fredrickson JM, Harker LA, Krause CJ, Schuller DE(eds) Otolaryngology, head and neck surgery, 3rd edn, Mosby. St Louis, p 2130 